\title{
Examining Social Capital for Urban Societies in the Midst of Covid-19 Through Digital Gotong Royong
}

\author{
Dodi Faedlulloh ${ }^{1, *}$ Vina Karmilasari ${ }^{2,}$ Intan Fitri Meutia ${ }^{3,}$ Devi Yulianti ${ }^{4}$ \\ 1, 2, 3, 4 Public Administration Department, Universitas Lampung \\ *Corresponding author. Email: dodi.faedlulloh@fisip.unila.ac.id
}

\begin{abstract}
Covid 19 attacks all aspects of human life on a global scale. The Indonesian government implemented a policy called Large-Scale Social Restrictions to reduce transmission. The mobility of people automatically changes due to these restrictions, especially in urban areas in Indonesia. Because high individual mobilization usually has to be limited, urban communities are affected more quickly. Despite the condition that still leaves a lot of structural homework to be burdened by the state, the concern for urban communities is slowly growing by working together to fight the Covid-19 pandemic in Indonesia. This paper aims to look critically at how urban societies face Covid-19 through digital mutual cooperation (gotong royong), which often occurs with the perspective of social capital. The research method used is a qualitative method with literature study. The results of the study show that social capital works like an "anchor" in digital mutual cooperation activities. The three aspects, namely networking, trust, and values and norms are intertwined in social capital.
\end{abstract}

Keywords: Covid 19, Digital Gotong Royong, Urban Societies, Social Capital

\section{INTRODUCTION}

After more than a year of the COVID-19 pandemic striking Indonesia, the curve has not shown any significant improvement. Until June 2021, there have been two million positive cases in Indonesia. Various policies have been carried out by the central government, but still cannot control the curve.

In dealing with the COVID-19 pandemic, Indonesia does not use the quarantine law. The Indonesian government uses the Large-Scale Social Restriction Policy (PSBB), which is currently being transformed into implementing restrictions on micro-community activities (PPKM-Mikro). With these restrictions, people's mobility automatically becomes very limited. In this case, urban societies who usually have very high mobility become very constrained.

People's mobility in countries with high social capital declines more rapidly [1]. This has implications for the process of handling COVID-19 carried out by the government to be faster. The interesting thing for the case in Indonesia is that mobility is tried to be suppressed but not accompanied by a comprehensive social protection program policy. Initial studies conducted by Yulianti, Meutia, Sujadmiko and Wahyudi
[2] showed that Indonesia was still slow in responding to the pandemic both from the dimensions of citizen behavior, government actions, and policy strength. In fact, the social assistance program was actually injured by the corrupt practices carried out by the Minister of Social Affairs [3]. In the midst of a pandemic, this case is certainly a blow to society.

COVID-19 jeopardizes the heath social security system's long-term viability financially [4]. Under these circumstances, Indonesia's social security system must be expanded to include new poor in addition to existing poor [5]. After more than a year, the COVID-19 epidemic is also having an effect on Indonesia's economic inequities. Numerous people have lost their jobs as a result of firms or enterprises suffering financial losses as a result of the COVID-19 outbreak. On the other hand, the number of wealthy and super-wealthy individuals in Indonesia is increasing [6].

Despite the fact that much structural work remains to be done and is the responsibility of the state, and regardless of the effectiveness of the government's intervention in dealing with the pandemic, public awareness is growing as a result of working collaboratively to combat the COVID-19 pandemic in Indonesia. Numerous social activities that are directly 
produced by metropolitan communities via the promotion of solidarity.

Since the outbreak of the Covid-19 epidemic, it has been declared a national disaster; the community has mobilised under the slogan "the people help the people." On the other side, people are adjusting their solidarity communities in specific locations, there is now also digital citizen solidarity with a broader coverage area. This program is dominated by urban-based creative minorities.

As shown in Table 1, during the epidemic and the ongoing policy process for dealing with COVID-19,

Table 1. Digital gotong royong in Indonesia during the covid-19 pandemic

\begin{tabular}{|c|c|c|c|c|}
\hline Platform Name & Type & How to Help & Who is being helped & Coverage Area \\
\hline Bagirata & $\begin{array}{c}\text { Gotong royong based } \\
\text { wealth distribution } \\
\text { platform }\end{array}$ & $\begin{array}{l}\text { Donations, volunteer } \\
\text { administrators and } \\
\text { platform developers }\end{array}$ & $\begin{array}{c}\text { Workers in the tourism, } \\
\text { hospitality, creative, } \\
\text { arts, culture, } \\
\text { entertainment and } \\
\text { gigeconomy sectors }\end{array}$ & $\begin{array}{l}\text { Throughout } \\
\text { Indonesia }\end{array}$ \\
\hline Mamajahit & $\begin{array}{c}\text { Provision of PPE for } \\
\text { Health Workers }\end{array}$ & Donations & $\begin{array}{c}\text { Hospital and puskesmas } \\
\text { health personnel }\end{array}$ & $\begin{array}{l}\text { Throughout } \\
\text { Indonesia }\end{array}$ \\
\hline Kawal Covid-19 & $\begin{array}{c}\text { The latest information } \\
\text { platform about Covid- } \\
19\end{array}$ & $\begin{array}{c}\text { Volunteer for technology, } \\
\text { data and content }\end{array}$ & Wide community & $\begin{array}{l}\text { Throughout } \\
\text { Indonesia }\end{array}$ \\
\hline Kawalrumahsakit.id & $\begin{array}{c}\text { Information platform } \\
\text { around the data needs } \\
\text { of medical / health } \\
\text { equipment in hospitals }\end{array}$ & $\begin{array}{c}\text { Volunteer data input and } \\
\text { monitoring of health } \\
\text { facilities needs }\end{array}$ & Wide community & $\begin{array}{l}\text { Throughout } \\
\text { Indonesia }\end{array}$ \\
\hline Bantumedis.com & $\begin{array}{l}\text { Information platform } \\
\text { around medical / } \\
\text { health device needs } \\
\text { data }\end{array}$ & $\begin{array}{c}\text { Donation of medical / } \\
\text { health equipment }\end{array}$ & Wide community & $\begin{array}{l}\text { Throughout } \\
\text { Indonesia }\end{array}$ \\
\hline Ayobergerak.id & $\begin{array}{l}\text { A platform that } \\
\text { supports the needs of } \\
\text { PPE for medical } \\
\text { personnel }\end{array}$ & Donations & Wide community & $\begin{array}{l}\text { Throughout } \\
\text { Indonesia }\end{array}$ \\
\hline Lapor Covid-19 & $\begin{array}{l}\text { The latest information } \\
\text { platform about Covid- } \\
19 \text { that the } \\
\text { government missed }\end{array}$ & $\begin{array}{c}\text { Volunteer for technology, } \\
\text { data and content }\end{array}$ & Wide community & $\begin{array}{l}\text { Throughout } \\
\text { Indonesia }\end{array}$ \\
\hline Sejutates.id & $\begin{array}{l}\text { Platform for access to } \\
\text { cheap antigen swab } \\
\text { test kits for the wider } \\
\text { community }\end{array}$ & $\begin{array}{l}\text { Donations, volunteer } \\
\text { administrators }\end{array}$ & Wide community & $\begin{array}{l}\text { Several cities in } \\
\text { Indonesia }\end{array}$ \\
\hline $\begin{array}{l}\text { practices in the midst of a w } \\
\text { that is also occurring in }\end{array}$ & $\begin{array}{l}\text { Indonesia. Not onl } \\
\text { Inigital transform }\end{array}$ & $\begin{array}{l}\text { activities to ass } \\
\text { take on a var }\end{array}$ & $\begin{array}{l}\text { st one another via dig } \\
\text { niety of forms. The }\end{array}$ & $\begin{array}{l}\text { gotong royong } \\
\text { wth of social }\end{array}$ \\
\hline \multicolumn{5}{|c|}{$\begin{array}{l}\text { disruption a change, but it is also a significant shift that } \\
\text { alters the established order. Citizens' efforts to assist one } \\
\text { another during a pandemic catastrophe are also altering } \\
\text { through the use of digital methods. Along with direct } \\
\text { solidarity initiatives carried out by individual groups or }\end{array}$} \\
\hline
\end{tabular}


On the basis of the foregoing, the authors are interested in undertaking preliminary study to better understand the dynamics of digital gotong royong in Indonesia, with a particular emphasis on urban societies' social capital. Social capital is critical in the middle of the COVID-19 pandemic. Citizenship standards promote collaboration and self-sacrifice for the common good, whereas social networks boost individual participation in maintaining social relationships, resulting in the opposite effect of pandemic-induced social isolation [10].

\section{METHOD}

The research design is a qualitative research approach that uses literature reviews to trace data and facts. Literature reviews help offer an analysis of the issue under investigation, analytical philosophical support, and information for research debate [11]. The information comes from a variety of publications, books, and authoritative news outlets. This study focuses on the social capital of urban societies through digital gotong royong, therefore the data obtained is based on an examination of the social media activities of the pioneers of digital gotong royong in Indonesia. The elements studied are networking, trust, and norms.

\section{RESULT AND ANALYSIS}

Social capital supports communities in a variety of ways during times of crisis, and communities with a high level of social capital respond more effectively than those with a low level of social capital [12]. Social capital can grow or dwindle. Numerous factors influence social capital. Social capital might be confusing during a pandemic. At the start of the pandemic, the population engaged in panic buying [13]. They shopped for everything necessary to assist themselves in large amounts. Due to these circumstances, certain products required during the epidemic became limited. Eventually, the product will become prohibitively pricey. These products are only available to those with a strong economic base and a large purchasing power. This situation demonstrates that the Indonesian people's social capital is at an all-time low. This is demonstrated by attempting to assist oneself rather than assisting others. Although the motivation is limited, temporary, and emotional [14], it demonstrates the ambiguity of social capital in urban societies. However, as time passed, the panic subsided. The society began assisting one another, for example, via digital gotong royong [15].

Sociologists defined social capital in the 1980s as the aggregate worth of individual relationships and reciprocal norms created through networks [16]. Numerous definitions of social capital have been proposed, the majority of which encompass related concepts. Social capital is a characteristic of social organizations that involves trust between individuals, codes of conduct, and interpersonal connections that can improve society's efficiency and build platforms that benefit many parties [17] [18].

The emergence of social media amplifies digital gotong royong. Social media's existence is recognized as a source of social capital [19]. It is vital to consider online social capital while discussing digital gotong royong. As a point of reference, while online and offline social capital are related, they are distinct entities [20].While offline social capital has been studied for decades, online social capital is a relatively recent phenomena that has garnered little scientific attention. As such, this paper will attempt to examine online social capital in the context of digital collaboration practices in Indonesian urban societies.

As this is a preliminary study, the analysis will focus on "capturing" various case studies of digital gotong royong in urban societies, with the research focus on three critical characteristics of social capital. While each element will cover a distinct scenario, it is adequate to demonstrate what is occurring on the ground. LaporCovid-19, Bagirata, and Sejutates.id are three digital gotong royong movements that will be analyzed using these social capital dimensions.

\subsection{Strengthen Networking}

Networking is a critical component of social capital. In the face of the community's limited mobility, social capital is required to enable members to assist one another [1]. As a result, networking becomes a critical component of social capital development.

One significant instance of networking practice is the installation of digital gotong royong in LaporCovid19. LaporCovid-19 is a "citizen coalition," and as such, strong networking amongst the members is required.

LaporCovid-19 employs a crowdsourcing technique that entails citizen participation in capturing COVID-19 numbers and reporting COVID-19-related issues, so serving as a conduit for tracking COVID-19 incidences in Indonesia [21]. The term "crowdsourcing" refers to a technique of outsourcing a job to a group of persons, a crowd, and relies on assets, knowledge, and skills to contribute value. LaporCovid-19 is a coalition of persons concerned about citizens' human rights and public health concerns in the aftermath of the COVID19 outbreak.

Although it is a group of individuals, it is inextricably linked to the organizational history of those involved in LaporCovid-19. Numerous individuals become "representatives" of various civil society organizations and mass media outlets, including the Indonesian Disaster and Crisis Journalists (JBK), the 
Indonesian Legal Aid Foundation (YLBHI), Tempo, Efek Rumah Kaca (ERK) Band, Transparency International Indonesia, Lokataru, Hakasasi.id, UInspire, STH Jentera, NarasiTV, and the Rujak Center for Urban Studies.

In social capital, networking refers to a group of people who are bound together by feelings of sympathy and obligation, as well as by exchange rules and civic involvement. The networking that took place at LaporCovid-19 was motivated by the same desire to comprehend the content of human rights. In this example, networking grows to seek justice and the fulfillment of human rights during a pandemic crisis.

Pandemics manifest themselves as natural disasters that cause widespread social disruption, job losses in specific industries, economic suffering, disease, and death [23]. However, the Indonesian government frequently responds late to epidemic policies [15].

This partnership was formed through networking that began long before the COVID-19 pandemic. Numerous civil society organizations and mass media outlets have historically worked both formally and informally in the implementation of Indonesia's human rights advocacy process. As a result, when the epidemic struck and the government was slow to respond, implying a disregard for people's human rights, they reformed a coalition, advocating for the community's access to health care as citizens. In this situation, it demonstrates indirectly that social capital can genuinely improve with frequent use. Networking becomes more robust as a result of continued use and utilization by a group of people engaged in collaborative activities. In other words, social capital enables the mobilization of resources through community networking [24], in this case the urban society via LaporCovid-19.

\subsection{Trust Without Knowing Each Other}

Social capital is critical to a democratic society's existence [25]. A civil society that is supported by social capital benefits from increased resilience as a result of the development of trust based on honesty and the concept of reciprocity. Trust is critical in the existence of a varied urban society.

Living together in an environment devoid of ethnic barriers is an unavoidable reality of global existence. Particularly in urban life, tight primal borders can no longer be used as a limiting factor.

This does not mean that in the heart of an urban culture tied by a capitalist lifestyle, one must negate the good that capitalism has to offer. While capitalism promotes globalization, which has succeeded in altering the "state of nature" of people's lives, people today live in a "world of strangers" in which all human behaviors, whether purposeful or not, have the potential to alter the lives of other humans, even strangers. in the past [26][27]. In this scenario trust in urban society plays a role.

A case in point of a trust-based approach in the practice of digital gotong royong is what occurred on the Bagirata platform. Bagirata is a cross-subsidy platform that aims to improve the financial situation of workers impacted by the economy during the COVID19 pandemic's uncertainty, by enabling the process of wealth transfer to affected workers in order to obtain the bare minimum required finances. These efforts are directed at: a) workers in the service, hospitality, tourism, health and pharmaceutical, and textile sectors who are forced to close or face unilateral layoffs; and b) workers in the media, creative, performing arts, culture, and entertainment sectors. company closures, project cancellations, event permits, and other stumbling blocks [28].

The process flow is quite simple. Namely, potential recipients must fill out a form that has been provided to explain how they were affected by the pandemic and the reasons why they need donations. Then, the shareholder verifies the profile of the prospective recipient. If you pass, the social media accounts of the prospective fund recipients will be displayed in profiles that can be seen by potential funders. Funders will be shown randomly 10 profiles of potential recipients. If there are stories and profiles of potential recipients that match the "criteria" of the funder, the donation can be directly transferred to the personal account of the potential recipient of funds. The algorithm prioritizes the profile of potential recipients of funds who have not received any donations at all. Bagirata does not store or manage the money disbursed. With the peer to peer model and connected to the social media profiles of potential recipients, funders can also directly monitor the online potential recipients of funds. The maximum amount that can be received by the beneficiary is IDR $1,500,000$, which refers to the provision of a decent standard of living in the Regulation of the Minister of Manpower and Transmigration No. 13 of 2012 [15].

The interesting element of Bagirata's practise is that there is an air of trust between a donor and a beneficiary who have never met. Donations are made based on the tales and profiles of possible receivers on social media. Bagirata's facilitation of interaction ultimately contributed to the development of trust between them [29], despite the fact that they met at random and did not know each other before.

Trust is something that is exchanged in accordance with agreed-upon standards for the benefit of the community. Reciprocity is necessary for trust. If both parties' expectations are met equally, a high level of trust can be achieved. The condition of solidarity among workers via Bagirata is a manifestation of the trust that 
develops in the context of shared fate as fellow working class members who are subject to the pandemic.

When associated with the government, Bagirata's practice of trust is paradoxical. Bagirata's presence is a result of the public's distrust of the government's performance in managing the pandemic and policy assurances to impacted populations. Bagirata is an inescapable indictment of society for "replacing" the state's duty in offering proactive measures to employees impacted by the COVID-19 pandemic. As fellow workers who are equally impacted, trust is built between those who retain economic privileges and those whose salaries are decreased or eliminated entirely as a result of the pandemic.

The preceding explanation demonstrates that Bagirata's practice of trust can transcend the standard definition of trust, which is always related with proximity, or in this case, the requirement of knowing one another. In other words, trust contributes to social transformation toward mutual solidarity.

Critically, Bagirata's approach is able to rethink the gotong royong story as it has been reshaped by the state into a political rhetorical instrument. On the other side, the narrative of Bagirata's digital gotong royong is that the government should not be the primary assister. Bagirata has become a beacon of optimism in the face of frequently cumbersome, poorly targeted, and even fraudulent government assistance initiatives [3].

\subsection{Extrapolating Values and Norms}

In general, norms are concrete values. Norms have a role related to social values. The main role of norms is to realise social values in society. On the other hand, value is an idea that has been passed down from generation to generation, which is considered true and important by members of a community group.

Norms are built to be a guide for everyone to behave under the rules that apply in society. Related to this, Putnam [30] explains that values are contained in a social network. In the context of urban community digital gotong royong, there are interesting findings; namely the values and norms prevailing in Indonesian society are active again, namely the norms of cooperation.

Norms are built and developed based on the history of cooperation in the past and applied to support a climate of cooperation [31]. In this aspect, the Sejutates.id case is a manifestation of the activation of cooperation norms in urban society.

The Solidarity Movement for a Million Antigen Tests for Indonesia is a social movement for access to cheap antigen swab test kits and reaches a wider audience. This movement raises funds collected through available donation channels. The Million Tests
Movement was initiated by individuals from various professional backgrounds [32]. In contrast to LaporCovid-19, which was initiated by many "activists" from civil society organizations, Sejutates.id was initiated by cross-professional individuals from several national figures including public health experts, academies, scientists, culturalists, entrepreneurs, politicians, artists, and even individuals. -individuals who have been part of the government who are part of the upper middle class of Indonesia. This solidarity movement also involves other stakeholders including the Ministry of Health and the National COVID-19 Task Force. This means showing the diversity of actors in community initiatives to help each other in the midst of a pandemic. However, there is a common substance between LaporCovid-19 and Sejutates.id, namely trying to involve the wider community in controlling the pandemic. The targets of the Sejutates.id movement are the epicenter areas of the pandemic, namely DKI Jakarta, West Java, and Banten.

In addition to access to cheap and affordable antigen swab test kits, Sejutastes.id also carries out the Oxygen for Citizens program, which is a free oxygen loan program for COVID-19 patients who are self-isolating.

Unlike LaporCovid-19 and Bagirata, which in practice can fully run mutual cooperation online, Sejutates.id certainly requires offline action. Therefore, in helping to spread the action of Oxygen for residents, Sejutates.id utilizes personal networking to build hubs outside Jakarta, Bogor, Depok, Tangerang, and Bekasi (Jabodetabek) as centers, namely in several cities including Garut, Cirebon, Bandar Lampung, Palembang, and Cilegon.

The practise of gotong royong through Sejutates.id involves the activation of prescriptive norms, a type of social capital that is critical in collectivities because it compels individuals to forego their own interests to behave in the collective's best interests. Social support, position, honor, and other awards serve to reinforce these standards. In this situation, the influential personalities behind Sejutates.id became their own allies in reviving social movements' resonance.

Essentially, not all shared norms and values that exist in society become social capital [33], but only those that are formed by the presence of trust. The established norms of cooperation were strengthened by the presence of trust, both in Sejutastes.id as an organization and in the individuals who founded Sejutates.id. This trust was successfully converted into social capital between Sejutates.id as a platform with donors and the beneficiary community.

\section{CONCULSION}

During a pandemic, social capital is critical for returning to function in acts to aid each other within the 
socieity. Social capital functions as a "anchor" in digital gotong royong activities in the context of urban life. Social capital and digital gotong royong are overdeterministic, which means they impact and strengthen one other during the COVID-19 pandemic's momentum.

The epidemic expands the LaporCovid-19 digital gotong royong's network footprint. In Bagirata's approach, trust is active even among persons who have never met before. Meanwhile, with the action of sejutates.id, societal norms and values, such as cooperation, are growing a new. In social capital, the three characteristics are interwoven.

Some of these profiles demonstrate the importance of social capital in the practise of supporting one another to replace the role of the legislation in providing public goods and services. In the context of digital gotong royong in urban socities, this is here to "replace" a state that has been tardy to provide affirmative measures in response to the COVID-19 epidemic. In the middle of a pandemic, social capital that has been transformed into a digital gotong royong practice has succeeded in bridging the spirit of human rights principles that are sensitive to degradation.

The findings of this study have ramifications for the study of social capital, which should be examined further in the context of dealing with the COVID-19 pandemic. An significant conclusion is that the mapping of social capital that is already taking place in urban neighborhoods is now extending out through digital media as well. When gotong royong activities are carried out digitally, the resonance is higher and the scope is wider than when these activities are carried out offline.

\section{AUTHORS' CONTRIBUTIONS}

Dodi Faedlulloh: Conceptualization, Formal Analysis, Writing- Original draft, Writing- Reviewing and Editing, Visualization. Vina Karmilsari: Formal Analysis, Writing- Reviewing and Editing. Intan Fitri Meutia: Writing- Reviewing and Editing. Devi Yulianti: Writing- Reviewing and Editing.

\section{ACKNOWLEDGMENTS}

Research activities at the Universitas Lampung are partly supported by DIPA BLU funds under the initiative of The Institute of Research and Community Service, Universitas Lampung (LPPM Unila). The authors would like to express gratitude to the leaders of FISIP Unila, LPPM Unila, and the Department of Public Administration Unila for their help in carrying out this study.

\section{REFERENCES}

[1] F. Borgonovi and E. Andrieu, "Bowling together by bowling alone: Social capital and COVID-19," Soc. Sci. Med., vol. 265, p. 113501, 2020, doi: 10.1016/j.socscimed.2020.113501.

[2] D. Yulianti, I. F. Meutia, B. Sujadmiko, and Wahyudi, "Indonesia ' Crisis Response To Covid-19 Pandemic: From Various Level of Government and Network Actions To Policy," J. Public Adm. Financ. Law Indones., no. 17, pp. 34-48, 2020.

[3] V. Lidyana, "Geger di Akhir Tahun, Korupsi Bansos Corona Terkuak,” Detik, 2020. https://finance.detik.com/berita-ekonomibisnis/d-5316714/geger-di-akhir-tahun-korupsibansos-corona-terkuak (accessed Jan. 18, 2021).

[4] R. Sparrow, T. Dartanto, and R. Hartwig, "Indonesia Under the New Normal: Challenges and the Way Ahead," Bull. Indones. Econ. Stud., vol. 56, no. 3, pp. 269-299, 2020, doi: 10.1080/00074918.2020.1854079.

[5] A. Suryahadi, R. Al Izzati, and D. Suryadarma, "Estimating the Impact of Covid-19 on Poverty in Indonesia*," Bull. Indones. Econ. Stud., pp. 175-192, 2020, doi: 10.1080/00074918.2020.1779390.

[6] E. Djumena, "Di Tengah Pandemi Covid-19, Jumlah Orang Kaya di Indonesia Meningkat," Kompas, 2021. https://www.kompas.com/tren/read/2021/07/17/ 093200465/di-tengah-pandemi-covid-19jumlah-orang-kaya-di-indonesia-meningkat-. (accessed Jul. 19, 2021).

[7] D. Faedlulloh, "Homo Cooperativus: Redefinisi Makna Manusia Indonesia," 2015.

[8] D. Faedlulloh, "Modal Sosial dan Praktik Gotong Royong Para Pengrajin Gula Kelapa di Desa Ketanda Kabupaten Banyumas," Publisia J. Ilmu Adm. Publik, vol. 2, no. 2, pp. 89-101, 2017.

[9] K. Lukiyanto and M. Wijayaningtyas, "Heliyon Gotong Royong as social capital to overcome micro and small enterprises ' capital dif fi culties," Heliyon, vol. 6, no. September, p. e04879, 2020, doi 10.1016/j.heliyon.2020.e04879.

[10] B. John (Jianqiu), S. Du, W. Jin, and C. Wan, "The Impact of Social Capital on Individual Responses to COVID-19 Pandemic: Evidence from Social Distancing," Shuili Jin, Wang Wan, Chi, Impact Soc. Cap. Individ. Responses to COVID-19 Pandemic Evid. from Soc. Distancing (June 14, 2020), 2020, doi: http://dx.doi.org/10.2139/ssrn.3609001.

[11] J. R. Fraenkel, N. E. Wallen, and H. H. Hyun, How to design and evaluate research in education. New York: McGraw Hill, 2012. 
[12] N. Pitas and C. Ehmer, "Social Capital in the Response to COVID-19," Am. J. Heal. Promot., vol. 34, no. 8, pp. 942-944, 2020, doi: $10.1177 / 0890117120924531$.

[13] H. Herjanto, M. Amin, and E. F. Purington, "Panic buying: The effect of thinking style and situational ambiguity," J. Retail. Consum. Serv., vol. 60, p. 102455, 2021, doi: https://doi.org/10.1016/j.jretconser.2021.102455

[14] T. Seno Aji, R. Indrarini, and C. Nikmah, "Rational Buying Motive and Emotional Buying of Consumers in the Era of Covid-19 Pandemic," Tech. Soc. Sci. J, vol. 17, p. 160, 2021.

[15] D. Faedlulloh, I. F. Meutia, D. Yulianti, and V. Karmilasari, "Gotong Royong Digital : Praktik Baru Solidaritas Warga di Era Pandemi," Jantra, vol. 16, no. 1, pp. 1-14, 2021.

[16] J. S. Coleman, "Social capital in the creation of human capital," Knowl. Soc. Cap., vol. 94, pp. 17-42, 2009, doi: 10.1086/228943.

[17] I. Kawachi, B. P. Kennedy, and R. Glass, "Social capital and self-rated health: A contextual analysis," Am. J. Public Health, vol. 89, no. 8, pp. 1187-1193, 1999, doi: 10.2105/AJPH.89.8.1187.

[18] L. Morales and K. Pilati, "The Role of Social Capital in," Int. J. Interdiscip. Soc. Sci., vol. 1, no. 1, pp. 101-126, 2011, doi: 10.1093/oxfordhb/9780199282944.003.0022.

[19] N. B. Ellison, C. Steinfield, and C. Lampe, "The benefits of facebook 'friends:' Social capital and college students' use of online social network sites," J. Comput. Commun., vol. 12, no. 4, pp. 1143-1168, 2007, doi: 10.1111/j.10836101.2007.00367.x.

[20] H. G. de Zúñiga, M. Barnidge, and A. Scherman, "Social Media Social Capital, Offline Social Capital, and Citizenship: Exploring Asymmetrical Social Capital Effects," Polit. Commun., vol. 34, no. 1, pp. 4468, 2017, doi: 10.1080/10584609.2016.1227000.

[21] Lapor Covid, "Tentang Kami," 2020. https://laporcovid19.org/tentang-kami (accessed Aug. 15, 2021).

[22] A. Dietrich and S. Amrein, Crowdfunding Monitoring Switzerland 2015. Lucerne Grafenauweg: School of Business, Institute of Financial Services Zug IFZ, 2015.

[23] V. Parks, "The Critical Role of Social Capital During the COVID-19 Pandemic: Lessons from Disaster Research," Inf. población, vol. 2, 2020.

[24] C. Wu, "Social capital and COVID-19: a multidimensional and multilevel approach," Chin. Sociol. Rev., vol. 53, no. 1, pp. 27-54, 2021, doi: 10.1080/21620555.2020.1814139.

[25] C. Wu, R. Wilkes, M. Fairbrother, and G. Giordano, "Social Capital, Trust, and State
Coronavirus Testing," Context, 2020. https://contexts.org/blog/healthcare-and-criticalinfrastructure/\#wu (accessed Jun. 27, 2021).

[26] J. Seglow, "The Ethics of Altruism: Introduction," in The Ethics of Altruism, J. Seglow, Ed. London: Portland: Frank Cass Pub, 2004.

[27] R. Robet, "Altruisme, Solidaritas dan Kebijakan Sosial," Masy. J. Sosiol., vol. 18, no. 1, pp. 118, 2013, doi: 10.7454/mjs.v18i1.4692.

[28] Bagirata, "BagiRata," Bagirata, 2020. https://bagirata.id/ (accessed Jan. 23, 2021).

[29] F. Fukuyama, "Sosial Capital: Civil Society and Development," Third World Q., vol. 22, 2001.

[30] R. . Putnam, Bowling Alone. The Collapse and Revival of American Community. New York: Simon and Schuster., 2000.

[31] R. . Putnam, Making Democracy Work: Civic Traditions in Modern Italy. Princeton: Princeton University Press., 1993.

[32] Sejutates.id, "Tentang Kami," 2020. https://sejutates.id/tentang-kami/ (accessed Aug. 15, 2021).

[33] F. Fukuyama, Trust: Kebijakan Sosial dan Penciptaan Kemakmuran. Yogyakarta: Penerbit Kalam, 2002. 